\title{
Words in Storybooks as Children's Language Input Environment: Predicates
}

\author{
Min Kyung Han, Si Yeon Seong, Sou Jin Choi \\ Department of Communication Disorders, Ewha Womans University, Seoul, Korea
}

Correspondence: Min Kyung Han, PhD Department of Communication Disorders, Ewha Womans University, 52 Ewhayeodae-gil, Seodamun-gu, Seoul 03760, Korea

Tel: $+82-2-3277-4012$

Fax: +82-2-3277-2122

E-mail:minhan@ewha.ac.kr

Received: January 5, 2016

Revised: February 10, 2016

Accepted: February 16, 2016

This work was supported by the BK21 Plus funded by the Ministry of Education of Korea.

\begin{abstract}
Objectives: The purpose of this study was to investigate the characteristics of the types and tokens of predicates in storybooks and to provide suggestions on the use of storybook predicates in research and clinical practice. Methods: Twenty-six books from each age group of 0-2, 3-4, and 5-7 years were selected, totaling 78 storybooks. Morphological analysis was conducted on 5,388 utterances containing predicates including verbs (Verb), adjectives (Adj), auxiliary verbs (Aux Verb), auxiliary adjectives (Aux Adj), positive copular (P Copula), and negative copula ( $\mathrm{N}$ Copula) in order to calculate the types and tokens of predicates across word classes and to determine the differences in the types and tokens of each word class across storybook age groups. Results: In the selected storybooks predicates represented $25.9 \%$ and $18.7 \%$ of the total types and tokens, respectively, with types and tokens increasing with age. The order of types from greatest to smallest across word classes was Verb $>$ Adj $>$ Aux Verb $>$ Aux Adj $>$ P Copula $=\mathrm{N}$ Copula and the frequency of tokens was Verb $>$ Adj $>$ Aux Verb $>$ P Copula $>$ Aux Adj $>$ N Copula. Across storybook age groups both type and token frequency for verbs increased significantly with age and decreased significantly for adjectives, and for auxiliary predicates the types decreased significantly with age whereas the token frequency increased significantly with age. Conclusion: Results show that the type and token frequency of verbs and auxiliary verbs increases with age in these storybooks. Thus, storybooks provide a language input environment that may positively influence syntactic development in children.
\end{abstract}

Keywords: Predicates, Storybooks, Morphological analysis, Type, Token
유아들은 생후 12 개월을 전후로 첫 낱말을 산출하고 생후 18 개 월 정도가 되면 두 낱말을 조합하기 시작한다. 아동은 명사 위주의 단일 단어 발화가 주를 이루었던 초기 언어 발달에서 두 낱말 조합 을 사용하면서 성인처럼 낱말을 조합하는 발화를 시작하고, 자신 의 의사표현을 좀 더 분명히 밝히기 시작한다. 두 낱말 조합은 일반 적으로 '대상+행위' 형식으로 나타나므로 명사와 함께 동사와 서 술 형용사들이 출현하며(Lee, 2009), 이 시기에는 특히 동사와 형용 사의 발달이 두드러진다(Lee, Lee, \& Jeon, 2004). 낱말 조합 시기는 아동이 많은 수의 용언을 습득하는 시기와 맞물려 용언 수의 증가 가 구문과 의미를 분화시켜 의사소통의도를 좀더 분명히 밝히는 등 문장을 완성해가는 시기이다(Tomasello, 1992).

한국어는 주어와 목적어의 생략이 자유로운 서술어 우위 언어이
고(Kim, 2004), 문장을 완성하기 위해서는 용언이 필요(Lee \& Im, 2003)하므로 한국어를 습득하여 사용하는 아동들에게 용언은 중 요한 의미를 갖는다. 한국 영유아를 대상으로 한 기존의 용언 연구 들 중 Choi와 Gopnik (1995)의 연구에 의하면, 일반적으로 어휘습 득과 언어발달에 있어서 어휘의 수가 이전보다 급격히 증가하는 어 휘폭발이 발생하는데 생후 19 개월의 한국 유아들에게서는 동사폭 발(verbs spurt) 현상이 발견된다고 보고하였다. 이러한 동사폭발 현상은 영어권에서는 나타나지 않지만 한국어에서는 나타나는 현 상이다. 이는 한국어가 ‘주어+목적어+서술어' 형식을 취하여 서술 어에 해당되는 품사인 동사가 문장의 끝에 제시되므로, 동사가 지 각적으로 더 두드러지고 빈번하게 사용되어 동사가 초기 어휘습득 에 많은 영향을 주기 때문이다. 
동사는 주체의 동작이나 과정을 나타내는 단어이고, 형용사는 주체의 상태나 성질을 나타낸다(Shin et al., 2012). 한국어에서 동사 와 형용사는 문장에서 서술어 기능을 하는 품사로, 어간만으로는 단어 구실을 하지 못하고 언제나 문법적 기능을 표시해주는 어미 를 취하는 특징을 가지는데 이 둘을 묶어 용언이라고 한다(Lee, Lee, \& Chai, 1997). 보조 용언은 동사와 형용사가 독자적으로 서술 어의 기능을 하지 못하고 다른 동사나 형용사에 의존하여 의미를 보충해 주는 보조적 역할을 하는 것으로, 보조동사나 보조형용사 로 부르게 되는데 이러한 보조용언은 본래의 의미를 상실하고 다 른 의미를 갖게 된다(Lee et al., 1997). 한편, 용언의 하위 범주로 서 술격조사 또는 지정사로 불리는 '이'는 긍정 지정사와 부정 지정사 로 나뉜다.

한국 영아들을 대상으로 초기 어휘발달을 살펴본 Chang-Song (2004)의 연구를 보면 한국 영아가 가장 많이 사용하는 동사는 주 다, 가다'라고 한다. 또한 초기 동사 출현에 있어서는 대화상대방인 어른의 언어입력 특성이 잘 반영되어 나타난다는 선행연구(Lee, 2009) 결과를 비추어 볼 때, 동사습득에 있어서 언어입력환경은 중 요한 역할을 한다고 할 수 있다. 형용사는 대상 자체가 아니라 색깔 이나 질감과 같은 대상의 속성을 기술하고, 수식하는 명사에 의존 적일 가능성이 있으므로 명사보다 습득하기 어려울 수 있다(Cho \& Lee, 2004). 이때 만 5세 유아들을 대상으로 동화책을 즐겨 읽는 정도가 언어능력에 미치는 영향을 살펴본 연구에서는, 책 읽기를 좋아하는 아동들이 사물을 설명할 때 위치를 나타내는 형용사나 부사 등의 수식어를 더 많이 사용하여 구체적인 설명이 가능하였 고, 복잡하고 긴 문장을 구사하며 그림에 나타나 있지 않은 사실에 대한 상상적인 설명도 더 많이 하는 것으로 나타났다(Kim \& Lee, 2001). 생후 24 개월부터 35 개월까지 총 11 개월에 걸쳐 4 명의 유아들 의 보조용언의 사용과 습득 과정을 살펴본 Chang, Jeon과 Kim (2014)의 연구 결과, 처음으로 출현하는 보조용언은 '주다, 말다, 보 다, 싶다'였으며 보조용언의 습득은 단계적으로 이루어지는 양상 을 보였다.

언어습득이론 중 사회적 화용이론(social-pragmatics theory)에 따르면, 아동의 초기 언어는 일상적이고 반복적인 상호작용 맥락 속에서 습득되며(Akhtar \& Tomasello, 2000), 언어입력환경이 언 어습득에 중요한 역할을 한다(Hart \& Risley, 1995; Huttenlocher, Haight, Bryk, Seltzer, \& Lyons, 1991). 이 이론에 따르면 동화책 읽 기 상호작용이 아동에게 초기 언어를 습득할 수 있는 언어환경을 제공한다고 할 수 있다. 동화책 읽기와 어휘 발달 간의 상관관계는 많은 연구들을 통해서 밝혀졌다.

최근에 발표된 Sosa (2016)의 연구에서도 유아와 부모의 놀이 상
황에서 다른 종류의 장난감보다 책 읽기 상호작용을 통하여 부모 의 표현어휘 수, 내용어, 대화 차례, 아동의 발성 빈도가 높게 나타 나 의사소통 상호작용을 촉진하여 언어발달에 긍정적인 영향을 미 치는 것으로 밝혀졌다. 어휘 습득에 있어서 어머니의 언어적 입력 의 양과 상호작용 유형의 영향을 살펴본 Chang-Song, Hong과 Lee (2007)의 연구에서는 아동의 어휘 습득을 위해 어머니가 무조건 말을 많이 하는 입력의 양보다 다양한 어휘를 많이 말하는 환경이 더 효과적이라고 하였다. 이 연구는 동화책을 읽어주는 사람이 다 양한 어휘를 사용하여 책을 읽어주는 상황이 어휘 습득에 있어서 중요하다는 점을 시사한다. 만 2 세 유아들과 그들의 부모를 대상으 로 책 읽기 상호작용이 어휘력과 어떤 관계가 있는지 살펴본 Lim과 $\operatorname{Kim}$ (2013)의 연구에서도 가정에서 부모가 아동과 함께하는 읽기 활동량이 많을수록 아동의 어휘력은 높게 나타났다.

많은 선행연구들이 동화책 읽기 상호작용과 아동의 초기 어휘 습득과의 관계를 밝히고 있지만 언어입력환경으로서 동화책 어휘 자체에 대한 연구는 미비한 편이다. 동화책은 다양한 상황과 맥락 을 제공함으로써 그 속에서 어휘를 일관적이고 반복적으로 아동에 게 노출시키는 언어입력환경의 역할을 한다(Han, Seong, \& Choi, 2015). "동화책 읽기를 통하여 입력된 단어는 심상어휘목록에 저장 되어 새로운 단어습득, 단어기억, 단어재인, 단어산출 등 아동의 언 어사용에 영향을 미친다(Han et al., 2015, p.491)." 본 원고에서는 취학 전 아동을 대상으로 발행된 동화책에서 사용된 단어의 형태 를 분석하여 용언의 유형 수와 사용빈도를 중심으로 형태적 특징을 연령별로 살펴보고 용언어휘목록의 활용방안을 제안하고자 한다.

본 연구의 궁극적인 목표는 동화책 어휘의 형태적 분석을 통해 만들어진 동화책 어휘목록을 제시하고, 이 어휘목록이 텍스트 분 량과 자료의 대표성 및 균형성을 확보한 문어(written language) 말 뭉치로서 역할을 하도록 하는 것이다. 동화책어휘 목록의 필요성과 활용 방법은 한국어 교육, 인접학문분야의 실험연구에 필요한 어 휘자료개발, 그리고 언어치료의 임상적 측면에서 살펴볼 수 있다. 한국어 교육 시, 동화책에 사용되는 단어는 취학 전 아동이나 한국 어를 제 2 외국어로 습득하는 외국인을 위한 한글 교육용 어휘목록 선정을 위한 기초자료를 제공할 것이다. 그리고 동화책 어휘목록은 인접학문분야의 실험연구에서 필요한 단어(예: 표준화된 어휘검사 도구 외에 수용어휘가 필요할 경우)를 선정할 때 단어어휘자료로 서의 역할을 할 수 있다. 또한 언어치료 중재프로그램에서 목표 단 어 선정 시 동화책 어휘를 활용하거나, 사회적 상호작용에 어려움 을 보이는 아동들이 다양한 상황과 맥락에서 사용되는 동화책 어 휘를 통하여 간접적인 상호작용을 경험하게 할 수 있을 것이다. 


\section{연구 방법}

\section{자료수집}

본 연구에서는 도서추천기관이 제공하는 추천도서목록을 사용 하여 0-7세의 취학 전 아동을 대상으로 2005년 1월부터 2015년 5월 까지 출간된 1,704 권의 그림책 중 연령별로 26 권씩 총 78 권의 도서 를 최종 선정하였다. 도서추천기관은 다음과 같은 기준으로 선정되 었다. 첫째, 많은 부모와아동들이 찾는 도서관들이 공신력 있는 도 서추천기관이 제공하는 도서목록을 바탕으로 도서를 선정하는 추 세(Cha, Kang, \& Jang, 2008; Kim, 2013)에 따라 추천도서목록을 제공하는 9 개의 기관과 출처를 찾았다. 그 기관과 출처는 어린이도 서연구회, 행복한 아침독서(책둥이), 북스타트 코리아, 어린이문화 진흥회, 네이버 통합검색, 고래가 숨쉬는 도서관, 어린이 평화책, 책 으로 따뜻한 세상 만들기 한우리독서문화운동본부, 국립어린이청 소년 도서관이었다. 둘째, 이들 중, 개별 홈페이지에서 취학 전 아동 을 대상으로 연령별 추천도서목록을 제공하는 비영리 단체인 어린 이도서연구회, 행복한 아침독서(책둥이), 북스타트 코리아를 선택 하여 이들이 제공하는 추천도서목록을 이용하였다.

연구에 사용할 도서목록에는 이들 세 개의 기관에서 제공하는 추천도서목록에서 문학, 과학, 인문, 사회, 예술 등 모든 장르의 도 서를 포함시키되 장르의 균형을 맞추기 위하여 전집류는 제외시켰 다. 연령은 추천도서목록에서 제공한 분류에 따라 크게 0-2세, 3-4 세, 5-7세로 나누었고, 각 기관의 추천도서가 중복되는 경우 연령 분류는 어린이도서연구회, 행복한 아침독서(책둥이), 북스타트코 리아 순서로 하였다. 어린이도서연구회가 도서의 권장연령을 가장 세분화시켰기 때문에 연령분류 기준의 우선순위로 두었으며, 북스 타트는 5-7세용 도서만을 추천하고 있기 때문에 연령분류 기준의 최하위 순위가 되었다. 한편, 추천도서목록에서 제시된 연령분류 (0-2세, 3-4세, 5-7세)에서 벗어나는 도서는 연구목록에서 제외시켰 다. 본 연구의 분석에 사용된 78권 동화책을 연령과 장르별로 분류 한 목록은 Appendix 1에 제시하였다.

\section{자료분석}

본 연구의 분석 대상이 된 78 권의 동화책에서 어른이 아동에게 읽어줄 것으로 예상되는 모든 텍스트, 즉 주석을 제외한 동화책 본 문 내용, 삽화나 말풍선 속에 포함된 글자를 분석하였다. 맞춤법과 띄어쓰기는 도서에 쓰여진 대로 분석하는 것을 원칙으로 하였으 며, 한글 맞춤법 오류를 방지하기 위해 한글문서에 먼저 전사한 후 형태소 분석기와의 호환성을 위해 텍스트 파일로 저장하여 사용 하였다. 형태소 분석을 위해 국립국어원에서 개발한 " 21 세기 세종
계획: 지능형 형태소 분석기 2.0 (깜짝새)" 프로그램을 사용하여 1 차 자동태깅을 하고, 프로그램의 자동태깅 오류를 수정하기 위해 2 차로 수동태깅을 하였다.

2 차 수동태깅 시에는 앞뒤 문맥에 따른 형태소의 의미를 고려하 여 분석하기 위해 한국어 형태소 및 어휘 사용 빈도의 분석 2 (Kang \& Kim, 2004)와 국립국어원 온라인 표준국어대사전(http://stdweb2.korean.go.kr/search/List_dic.jsp)의 품사 분류기준을 따랐으 며, 보충설명이 필요할 경우 표준국어문법론(Nam \& Ko, 1993)을 참고하였다. 또한 형태소 분석기 프로그램에서 오류가 자주 발생하 는 일부 형태소에 대해 일관성 있는 분석을 하기 위해 본 저자들이 다음과 같은 분석기준을 세웠다. 첫째, 명사를 꾸며주는 수 관형사 는 관형사로 간주한다(예: 일곱 개 $\rightarrow$ 일곱(관형사) + 개(의존명사)). 둘째, 일반명사가 등장인물의 이름으로 쓰였을 경우 고유명사로 간 주한다. 셋째, 준말과 본딧말은 각각 별개의 단어로 분석하였다. 넷 째, 의성어와 의태어 사이에 있는 기호는 분석에서 제외한다(예: 부 $\sim$ 웅 $\rightarrow$ 부웅(일반부사) $+\sim($ 붙임표)). 다섯째, 의성어와 의태어는 모 두 부사로 분석하고, 본문의 띄어쓰기를 따른다[예: 깡총깡총 $\rightarrow$ 깡 총깡총(일반부사)]. 여섯째, 합성어나 파생어의 경우 하나의 형태소 로 취급한다[예: 꽃밭 $\rightarrow$ 꽃밭(일반명사)]. 일곱째, 강조된 부사어는 각각 따로 분석한다[예: 너무너무 $\rightarrow$ 너무(일반부사) + 너무(일반부 사)]. 여덟째, 웃음소리는 의성어로, 감탄사가 아닌 부사로 분석한다. 수동태깅의 오류를 줄이기 위해 두 차례의 수동태깅을 실시하였는 데, 1 차 수동태깅과 2 차 수동태깅 사이의 신뢰도 평균은 $93.8 \%$ 였다.

본 연구의 분석 대상이 된 78 권의 도서는 총 14,728 어절로, $0-2$ 세 도서는 1,299어절, 3-4세용 도서는 5,015어절, 5-7세용 도서는 8,414 어절이었다. 이 중 용언은 5,388 어절이었다. 용언의 품사별 하위분 류인 ‘동사, 형용사, 보조용언, 긍정지정사, 부정지정사’를 형태소 분 석기를 통해 분석한 후, 보조용언을 수동으로 보조동사와 보조형 용사로 세분화시켰다. 그 결과, 본 연구에서는 동사, 형용사, 보조동 사, 보조형용사, 긍정지정사, 부정지정사를 최종 분석 요소로 삼아 이들 품사에 새로 등장하는 낱말 수(유형 수)와 사용된 낱말의 총 수(사용빈도)를 중심으로 형태적 특징을 살펴보았다. 구체적으로 첫째, 분석대상이 된 동화책 전체에서 사용된 단어 총 유형 수와 사용빈도를 연령별로 계산한 후 이들 중 용언의 유형 수와 사용빈 도를 계산하였고, 둘째, 용언을 품사별로 분류해 각 품사별 유형 수 와 사용빈도를 연령별로 계산하였으며, 셋째, 용언의 품사별 유형 수와 사용빈도가 연령 간 통계적으로 유의미한 차이가 있는지 살 펴보기 위해 일원분산분석을 실시하였다. 
Table 1. Type and token ratio of predicates in total vocabularies

\begin{tabular}{lrr}
\hline Age (yr) & \multicolumn{1}{c}{ Type } & \multicolumn{1}{c}{ Token } \\
\hline Total & $1,234 / 4,770(25.9)$ & $5,388 / 28,850(18.7)$ \\
$0-2$ & $114 / 555(20.5)$ & $386 / 2,264(17.0)$ \\
$3-4$ & $454 / 1,856(24.5)$ & $1,780 / 9,894(18.0)$ \\
$5-7$ & $666 / 2,359(28.2)$ & $3,222 / 16,692(19.3)$ \\
\hline
\end{tabular}

Values are presented as the number of substantives/total (\%).

\section{연구 결과}

Table 1에서 알 수 있듯이, 본 연구는 0-7세용 동화책에 출현한 단 어 총 유형 수 4,770 개, 총 사용빈도 28,850 회 중 용언에 해당하는 유형 수 1,234 개, 사용빈도 5,388 회를 분석대상으로 하였다. 연령별 로 살펴보면, 0-2세용 도서에서 용언의 유형 수가 114 개로 이 연령 대에서 출현하는 총 유형 수의 $20.5 \%$ 를 차지하였고, 사용빈도는 386 회로 이 연령대 총 사용빈도의 $17.0 \%$ 로 나타났다. 3-4세용 도서 에서 용언의 유형 수가 454개로 이 연령대에서 출현하는 총 단어 유형 수의 $24.5 \%$ 를 차지하였고, 사용빈도는 1,780 회로 이 연령대 총 사용빈도의 $18.0 \%$ 로 나타났다. 5-7세용 도서에서는 용언의 유 형 수가 666 개로 이 연령에서 출현하는 총 단어 유형 수의 $28.2 \%$ 를 차지하였고, 사용빈도가 3,222 회로 이 연령대 총 사용빈도의 $19.3 \%$ 로 나타났다.

동화책에 등장하는 용언을 품사 유형별로 살펴보면(Table 2), 동 사가 0-2세용 도서에서 $61.4 \%, 3-4$ 세용 도서에서는 75.4\%, 5-7세용 도서에서는 $78.6 \%$ 를 차지하여 모든 연령대에서의 도서에서 가장 많은 비중을 차지하였는데, 용언의 다른 품사들보다 압도적으로 높 게 나타났다. 용언의 품사별 비중은 모든 연령에서 동사>형용사> 보조동사 $>$ 보조형용사 $>$ 긍정지정사 $=$ 부정지정사의 순서로 나타 났다. 한편 사용빈도에 있어서도 동사가 각 연령대에서 가장 많은 빈도를 차지하였는데 0-2세용 도서에서 59.3\%, 3-4세용 도서에서 는 $58.4 \%, 5-7$ 세용 도서에서는 $62.0 \%$ 로 나타났다. 형용사의 사용빈 도는 0-2세용 도서에서 $20.5 \%, 3-4$ 세용 도서에서는 $22.5 \%, 5-7$ 세용 도서에서는 $16.8 \%$ 를 차지하여 모든 연령에서 동사 다음으로 빈번 하게 사용되었다. 품사들의 용언 내 사용빈도는 모든 연령에서 동 사 $>$ 형용사 $>$ 보조동사 $>$ 긍정지정사 $>$ 보조형용사 $>$ 부정지정사의 순서를 보였다.

\section{품사별 유형 수 및 사용빈도의 연령별 차이}

용언의 품사별 유형 수와 사용빈도의 연령별 차이를 살펴보기 위해 일원분산분석을 실시하였는데 그 결과는 Table 3과 같다.
Table 2. Type and token ratio of word classes in total predicates

\begin{tabular}{|c|c|c|c|}
\hline Age (yr) & Word class & Type & Token \\
\hline Total & $\begin{array}{l}\text { Verb } \\
\text { Adj } \\
\text { Aux Verb } \\
\text { Aux Adj } \\
\text { P Copula } \\
\text { N Copula } \\
\text { Sum }\end{array}$ & $\begin{array}{c}937(75.9) \\
233(18.9) \\
48(3.9) \\
10(.8) \\
3(.2) \\
3(.2) \\
1,234(100)\end{array}$ & $\begin{array}{c}3,265(6.6) \\
1,021(19.0) \\
592(11.0) \\
71(1.3) \\
398(7.4) \\
40(.7) \\
5,387(100)\end{array}$ \\
\hline $0-2$ & $\begin{array}{l}\text { Verb } \\
\text { Adj } \\
\text { Aux Verb } \\
\text { Aux Adj } \\
\text { P Copula } \\
\text { N Copula } \\
\text { Sum }\end{array}$ & $\begin{array}{c}70(61.9) \\
33(29.2) \\
7(6.2) \\
1(.9) \\
1(.9) \\
1(.9) \\
113(100)\end{array}$ & $\begin{array}{c}229(59.3) \\
79(2.5) \\
39(10.1) \\
2(.5) \\
36(9.3) \\
1(.3) \\
386(100)\end{array}$ \\
\hline $3-4$ & $\begin{array}{l}\text { Verb } \\
\text { Adj } \\
\text { Aux Verb } \\
\text { Aux Adj } \\
\text { P Copula } \\
\text { N Copula } \\
\text { Sum }\end{array}$ & $\begin{array}{c}344(75.4) \\
88(19.3) \\
18(3.9) \\
4(.9) \\
1(.2) \\
1(.2) \\
456(100)\end{array}$ & $\begin{array}{c}1,039(58.4) \\
401(22.5) \\
167(9.4) \\
21(1.2) \\
127(7.1) \\
25(1.4) \\
1,780(100)\end{array}$ \\
\hline $5-7$ & $\begin{array}{l}\text { Verb } \\
\text { Adj } \\
\text { Aux Verb } \\
\text { Aux Adj } \\
\text { P Copula } \\
\text { N Copula } \\
\text { Sum }\end{array}$ & $\begin{array}{c}523(78.6) \\
112(16.8) \\
23(3.5) \\
5(.8) \\
1(.2) \\
1(.2) \\
665(100)\end{array}$ & $\begin{array}{c}1,997(62.0) \\
541(16.8) \\
386(12.0) \\
48(1.5) \\
235(7.3) \\
14(.4) \\
3,221(100)\end{array}$ \\
\hline
\end{tabular}

Values are presented as the number $(\%)$.

Verb=verb; Adj=adjective; Aux Verb=auxiliary verb; Aux Adj=auxiliary adjective; P Copula = positive copula; $\mathrm{N}$ Copula = negative copular .

\section{동사}

동사의 경우, 유형 수의 평균(표준편차)은 0-2세 3.96 (2.95)개, 3-4세 26.73 (16.41)개, 5-7세 45.81 (30.25)개였으며, 연령별 유형 수 는 통계적으로 유의미한 차이를 보였다 $\left(F_{(2,75)}=28.70, p<.05\right)$. Bonferroni 사후검증 결과, 동사의 유형 수는 모든 연령대 도서에서 상 호 유의미한 차이를 보였다. 연령별 동사의 사용빈도 평균(표준편 차)은 0-2세 8.81 (5.52)회, 3-4세 39.96 (28.40)회, 5-7세 76.81 (53.26) 회로 나타났고, 연령별 사용빈도가 통계적으로 유의미한 차이를 보 였다 $\left(F_{(2,75)}=24.60, p<.05\right)$. Bonferroni 사후검증 결과, 동사의 사 용빈도에서도 모든 연령대 도서에서 상호 유의미한 차이를 보였다.

\section{형용사}

형용사의 경우, 유형 수의 평균(표준편차)은 0-2세 1.81 (2.32)개, 3-4세 8.50 (5.05)개, 5-7세 11.96 (6.14)개였으며, 연령별 유형 수는 통계적으로 유의미한 차이를 보였다 $\left(F_{(2,75)}=30.29, p<.05\right)$. Bonferroni 사후검증 결과, 형용사의 유형 수는 모든 연령대 도서에서 상 
Table 3. Descriptive statistics and ANOVA results of types and tokens of predicates

\begin{tabular}{|c|c|c|c|c|c|c|c|c|c|c|c|}
\hline \multirow{2}{*}{ Word class } & \multirow{2}{*}{ Age (yr) } & \multicolumn{5}{|c|}{ Type } & \multicolumn{5}{|c|}{ Token } \\
\hline & & $M$ & SD & Min & Max & $F$ & $M$ & SD & Min & Max & $F$ \\
\hline Verb & $\begin{array}{l}0-2 \\
3-4 \\
5-7\end{array}$ & $\begin{array}{r}3.96 \\
26.73 \\
45.81\end{array}$ & $\begin{array}{r}2.95 \\
16.41 \\
30.25\end{array}$ & $\begin{array}{l}0 \\
5 \\
6\end{array}$ & $\begin{array}{r}9 \\
61 \\
114\end{array}$ & $28.70^{*}$ & $\begin{array}{r}8.81 \\
39.96 \\
76.81\end{array}$ & $\begin{array}{r}5.52 \\
28.40 \\
53.26\end{array}$ & $\begin{array}{r}0 \\
5 \\
10\end{array}$ & $\begin{array}{r}20 \\
105 \\
179\end{array}$ & $24.60^{*}$ \\
\hline Adj & $\begin{array}{l}0-2 \\
3-4 \\
5-7\end{array}$ & $\begin{array}{r}1.81 \\
8.50 \\
11.96\end{array}$ & $\begin{array}{l}2.32 \\
5.05 \\
6.14\end{array}$ & $\begin{array}{l}0 \\
0 \\
2\end{array}$ & $\begin{array}{r}9 \\
18 \\
25\end{array}$ & $30.29^{*}$ & $\begin{array}{r}3.04 \\
15.42 \\
20.81\end{array}$ & $\begin{array}{r}4.55 \\
10.67 \\
12.32\end{array}$ & $\begin{array}{l}0 \\
0 \\
2\end{array}$ & $\begin{array}{l}19 \\
41 \\
58\end{array}$ & $22.61^{*}$ \\
\hline Aux Verb & $\begin{array}{l}0-2 \\
3-4 \\
5-7\end{array}$ & $\begin{array}{r}.65 \\
3.54 \\
6.19\end{array}$ & $\begin{array}{r}.85 \\
2.79 \\
3.61\end{array}$ & $\begin{array}{l}0 \\
0 \\
1\end{array}$ & $\begin{array}{r}3 \\
9 \\
16\end{array}$ & $27.79^{*}$ & $\begin{array}{r}1.50 \\
6.42 \\
14.85\end{array}$ & $\begin{array}{r}2.67 \\
6.51 \\
10.36\end{array}$ & $\begin{array}{l}0 \\
0 \\
1\end{array}$ & $\begin{array}{l}11 \\
22 \\
37\end{array}$ & $22.66^{*}$ \\
\hline Aux Adj & $\begin{array}{l}0-2 \\
3-4 \\
5-7\end{array}$ & $\begin{array}{l}.08 \\
.54 \\
.19\end{array}$ & $\begin{array}{l}.27 \\
.76 \\
.98\end{array}$ & $\begin{array}{l}0 \\
0 \\
0\end{array}$ & $\begin{array}{l}1 \\
3 \\
4\end{array}$ & $15.18^{*}$ & $\begin{array}{r}.08 \\
.81 \\
1.85\end{array}$ & $\begin{array}{r}.27 \\
1.44 \\
1.87\end{array}$ & $\begin{array}{l}0 \\
0 \\
0\end{array}$ & $\begin{array}{l}1 \\
6 \\
7\end{array}$ & $10.91^{*}$ \\
\hline P Copula & $\begin{array}{l}0-2 \\
3-4 \\
5-7\end{array}$ & $\begin{array}{l}.38 \\
.77 \\
.92\end{array}$ & $\begin{array}{l}.50 \\
.43 \\
.27\end{array}$ & $\begin{array}{l}0 \\
0 \\
0\end{array}$ & $\begin{array}{l}1 \\
1 \\
1\end{array}$ & $11.89^{*}$ & $\begin{array}{l}1.38 \\
4.88 \\
9.04\end{array}$ & $\begin{array}{l}3.65 \\
5.64 \\
5.60\end{array}$ & $\begin{array}{l}0 \\
0 \\
0\end{array}$ & $\begin{array}{l}18 \\
21 \\
20\end{array}$ & $14.96^{*}$ \\
\hline N Copula & $\begin{array}{l}0-2 \\
3-4 \\
5-7\end{array}$ & $\begin{array}{l}.04 \\
.31 \\
.35\end{array}$ & $\begin{array}{l}.20 \\
.47 \\
.49\end{array}$ & $\begin{array}{l}0 \\
0 \\
0\end{array}$ & $\begin{array}{l}1 \\
1 \\
1\end{array}$ & $4.43^{*}$ & $\begin{array}{l}.04 \\
.96 \\
.54\end{array}$ & $\begin{array}{r}.20 \\
2.24 \\
.90\end{array}$ & $\begin{array}{l}0 \\
0 \\
0\end{array}$ & $\begin{array}{r}1 \\
10 \\
3\end{array}$ & 2.84 \\
\hline
\end{tabular}

Verb=verb; Adj= adjective; Aux Verb= auxiliary verb; Aux Adj= auxiliary adjective; P Copula= positive copula; N Copula= negative copular. ${ }^{*} p<.05$.

호 유의미한 차이를 보였다. 연령별 형용사의 사용빈도 평균(표준 편차)은 0-2세 3.04 (4.55)회, 3-4세 15.42 (10.67)회, 5-7세 20.81 (12.32) 회로 나타났고, 연령별 사용빈도가 통계적으로 유의미한 차이를 보 였다 $\left(F_{(2,75)}=22.61, p<.05\right)$. Bonferroni 사후검증 결과, 형용사의 사용빈도에서 0-2세와 3-4세, 0-2세와 5-7세 사이에서 유의미한 차 이가 나타났고, 3-4세와 5-7세 사이에서는 유의미한 차이를 보이지 않았다.

\section{보조동사}

보조동사의 경우, 유형 수 평균(표준편차)은 0-2세 .65 (.85)개, 3-4세 3.54 (2.79)개, 5-7세 6.19 (3.61)개였으며, 연령별 유형 수는 통 계적으로 유의미한 차이를 보였다 $\left(F_{(2,75)}=27.79, p<.05\right)$. Bonferro$\mathrm{ni}$ 사후검증 결과, 보조동사의 유형 수는 모든 연령대 도서에서 상 호 유의미한 차이를 보였다. 연령별 보조동사의 사용빈도 평균(표 준편차)은 0-2세 1.50 (2.67)회, 3-4세 6.42 (6.51)회, 5-7세 14.85 (10.36) 회로 나타났고, 연령별 사용빈도가 통계적으로 유의미한 차이를 보 였다 $\left(F_{(2,75)}=22.66, p<.05\right)$. Bonferroni 사후검증 결과, 보조동사의 사용빈도에서도 모든 연령대 도서에서 상호 유의미한차이가 보였다.

\section{보조형용사}

보조형용사의 경우, 유형 수 평균(표준편차)은 0-2세 0.08 (0.27) 개, 3-4세 0.54 (0.76)개, 5-7세 1.19 (0.98)개였으며, 연령별 유형 수는
통계적으로 유의미한 차이를 보였다 $\left(F_{(2,75)}=15.18, p<.05\right)$. Bonferroni 사후검증 결과, 보조형용사의 유형 수는 0-2세를 제외한 모든 연령대 도서에서 상호 유의미한 차이를 보였다. 연령별 보조형용사 의 사용빈도 평균(표준편차)은 0-2세 0.08 (0.27)회, 3-4세 0.81 (1.44) 회, 5-7세 1.85 (1.87)회로 나타났고, 연령별 사용빈도가 통계적으로 유의미한 차이를 보였다 $\left(F_{(2,75)}=10.91, p<.05\right)$. Bonferroni 사후검 증 결과, 보조형용사의 사용빈도에서도 0-2세를 제외한 모든 연령 대 도서에서 상호 유의미한차이를 보였다.

\section{긍정지정사}

긍정지정사의 경우, 유형 수 평균(표준편차)은 0-2세 $0.38(0.50)$ 개, 3-4세 0.77 (0.43)개, 5-7세 0.92 (0.27)개였으며, 연령별 유형 수 는 통계적으로 유의미한 차이를 보였다 $\left(F_{(2,75)}=11.89, p<.05\right)$. Bonferroni 사후검증 결과, 긍정지정사의 유형 수는 0-2세와 3-4세, 0-2 세와 5-7세 사이에서 유의미한 차이가 나타났고, 3-4세와 5-7세 사 이에서는 유의미한 차이를 보이지 않았다. 연령별 긍정지정사의 사 용빈도 평균(표준편차)은 0-2세 1.38 (3.65)회, 3-4세 4.88 (5.64)회, 5-7세 9.04 (5.60)회로 나타났고, 연령별 사용빈도가 통계적으로 유 의미한 차이를 보였다 $\left(F_{(2,75)}=14.96, p<.05\right)$. Bonferroni 사후검증 결과, 긍정지정사의 사용빈도에서 모든 연령대 도서에서 상호 유의 미한차이를 보였다. 


\section{부정지정사}

부정지정사의 경우, 유형 수 평균(표준편차)은 0-2세 .04 (.20)개, 3-4세 .31 (.47)개, 5-7세 .35 (.49)개였으며, 연령별 유형 수는 통계적 으로 유의미한 차이를 보였다 $\left(F_{(2,75)}=4.43, p<.05\right)$. Bonferroni 사 후검증 결과, 부정지정사의 유형 수는 0-2세와 5-7세 사이에서만 유 의미한 차이가 나타났고, 다른 연령대 사이에서는 유의미한 차이 를 보이지 않았다. 연령별 부정지정사의 사용빈도 평균(표준편차) 은 0-2세 .04 (.20)회, 3-4세 .96 (2.24)회, 5-7세 .54 (.90)회로 나타났 고, 연령별 사용빈도가 통계적으로 유의미한 차이를 보이지 않았 다 $\left(F_{(2,75)}=2.84, p>.05\right)$.

\section{논의 및 결론}

본 연구는 취학 전 아동의 언어입력환경으로서 중요한 역할을 하 는 동화책 어휘에서 용언을 구성하는 동사, 형용사, 보조동사, 보조형 용사, 긍정지정사, 부정지정사의 형태적 분석을 통해 나타난 특성을 살펴보고 문어자료에서 용언목록의 활용방안을 모색하고자 하였다.

\section{용언의 유형 수와 사용빈도}

본 연구에서 분석된 78권의 동화책에서 용언의 유형 수는 전체 품사 유형 수의 $25.9 \%$, 사용빈도 비율은 품사 전체 사용빈도의 $18.7 \%$ 였다. 동화책 단어를 분석한 Lee와 Kim (2004)에서는 용언의 유형 수가 전체 품사의 $32.5 \%$, 사용빈도 비율이 품사 전체 사용빈 도의 $38.9 \%$ 로 나타나 본 연구보다 높은 수치를 보였다. 또한 본 연 구에서는 전체 품사에서 용언의 유형 수와 사용빈도가 5-7세>3-4 세>0-2세용 도서 순으로 나타나 동화책에서는 연령이 높아질수 록 용언의 유형 수와 사용빈도가 증가함을 알 수 있다. Lee와 Kim (2004)의 연구에서는 어휘 수의 경우 5-6세>3-4세 도서 순서로 증 가하였으나 어휘 빈도에 있어서는 연령에 따른 변화가 거의 없었다. 그러나 본 연구와 Lee와 Kim (2004)의 연구는 대상 연령구분, 분석 자료 및 요소, 자료의 크기 등 연구 방법에서 많은 차이가 있기 때 문에 직접적인 비교를 하기는 어렵다. 본 연구와 동일한 연구 방법 으로 체언을 분석한 $\operatorname{Han}$ 등(2015)에서 체언의 유형 수는 3-4세 >5-7세>0-2세용 도서 순서로 많았고, 연령이 높을 수록 사용빈 도가 감소하였다. 본 연구에서 분석 대상이 된 동화책에 등장한 낱 말 전체에서 용언의 유형 수와 사용빈도를 살펴본 결과, 체언과 비 교하여 용언은 연령이 높아질수록 유형 수와 사용빈도가 모두 증 가하여 동화책에 사용되는 체언과 용언이 연령에 따라 다른 사용 양상을 보이는 것을 알 수 있다.

동화책 전체(0-7세)에서 용언을 품사별로 살펴볼 때, 동사>형용
사>보조동사>보조형용사>지정사의 순서로 유형 수와 사용빈도 가 나타났다. 이러한 순서는 만 2-5세 아동의 자발화에서 용언을 분 석한 Oh, Cha, Yoon, Kim과 Chang (2014)의 연구결과와 비슷한 것 이다. 그리고 동사와 형용사가 용언에서 차지하는 유형 수와 사용 빈도의 비율을 볼 때, 유형 수의 경우 본 연구에서는 동사(937개)가 형용사(233개)의 약 4 배를 차지하는 데 비해 $\mathrm{Oh}$ 등(2014)의 연구에 서는 동사(599개)가 형용사(190개)의 약 3 배를 차지하고, 사용빈도 의 경우 본 연구에서는 동사(3,265회)가 형용사(1,021회)의 약 3 배 를, $\mathrm{Oh}$ 등(2014)의 연구에서는 동사(12,722회)가 형용사(5,459회) 의 약 2 배를 차지하였다. 따라서 동화책과 자발화 모두 전체 용언 내 품사에서 동사가 차지하는 유형 수와 사용빈도 비율이 형용사 에 비해 압도적으로 많고, 자발화에 비해 동화책에서 그 비율이 더 컸다. 동화책에서 동사가 형용사보다 더 다양하게 자주 사용되는 이유는 동화책 대상 연령이 높아지면서 체언의 사용빈도가 감소하 는 데서 찾을 수 있다. 즉 형용사는 대상의 속성을 기술하며 자신이 수식하는 체언에 의존하게 되는데, 체언의 사용빈도가 감소하면서 체언을 수식하는 형용사의 유형 수와 사용빈도도 자연스럽게 줄어 든 것이다. 본 연구에서 용언을 품사별로 분류하여 유형 수와 사용 빈도를 살펴본 결과, 아동은 동화책을 통하여 다른 어떤 용언 품사 보다도 더 다양한 종류의 동사에 빈번하게 노출될 것으로 보인다.

동사, 형용사, 보조용언이 차지하는 비율을 연령별로 살펴보면, 0-2세용 동화책에 등장하는 단어 전체 유형 수 중에서 동사는 $61.9 \%$, 형용사는 $29.2 \%$, 보조용언은 $7.2 \%, 3-4$ 세용 동화책에서는 동사 $75.4 \%$, 형용사 $19.3 \%$, 보조용언 $4.8 \%, 5-7$ 세용 동화책에서는 동사 $78.6 \%$, 형용사 $16.8 \%$, 보조용언 $4.3 \%$ 를 차지하였다. 따라서 대상 연령이 높은 동화책일수록 동사의 유형 수가 증가하는 데 비해 형 용사와 보조용언의 유형 수는 상대적으로 줄어드는 것을 알 수 있 다. 그 사용빈도에 있어서 동사, 형용사, 보조용언은 0-2세(동사 $59.3 \%$, 형용사 $20.5 \%$, 보조용언 $10.6 \%$ ), 3-4세용(동사 $58.4 \%$, 형용사 $22.5 \%$, 보조용언 $10.6 \%$ ) 동화책에서는 연령별 차이가 없다가 5-7세 용 동화책에서 동사(62.0\%)와 보조용언(13.5\%)의 사용빈도 비율 이 증가하고 형용사의 사용빈도(16.8\%)가 감소하였다. 따라서 동화 책에서는 대상 연령이 높을수록 동사의 유형 수와 사용빈도가 증 가하는 데 비해 형용사의 유형 수와 사용빈도는 감소하고, 보조용 언의 유형 수는 감소하나 사용빈도는 증가하는 특징을 보인다. 본 연구에서 용언을 품사별로 분류하여 유형 수와 사용빈도를 연령에 따라 살펴보았을 때, 동화책 대상 연령 증가와 모든 용언 품사의 유 형 수와 사용빈도 증가가 정비례하는 것은 아니라는 점을 알 수 있 다. 동화책에서는 대상 연령이 높아질수록 다른 품사보다 동사를 더 다양하게 자주 사용하는 것으로 나타났다. 


\section{연령별 용언 품사의 특징}

용언을 구성하는 품사들 중 동사와 보조동사의 유형 수와 사용 빈도는 모든 연령 간 유의미한 차이가 있었다. 형용사는 사용빈도 에서, 보조형용사에서는 유형 수와사용빈도에서, 긍정지정사는 유 형 수에서, 긍정지정사는 유형 수와 사용빈도에서 연령 간 유의미 한 차이가 없는 연령대가 있었다.

\section{동사}

같은 품사 내 연령 간 차이를 비교해 보면, 동사의 경우, 0-2세, 3-4세, 5-7세 사이의 유형 수와 사용빈도가 모두 유의미하였다. 본 연구에서 0-2세는 만 나이로 약 0-1;11 (0-23개월)로 명사중심의 단 일 단어 발화기에서 두 단어를 조합하면서 동사가 등장하는 시기 를 거치게 된다. 12-23개월의 아동의 자발화를 연구한 Lee 등(2004) 에 따르면, $12-16$ 개월 사이에 아동은 명사 중심의 단일 단어를 발화 하다 17-20개월에는 두 단어를 조합하면서 동사를 사용하기 시작 하는 품사 확장기를 맞이한다. 그리고 부모가 보고한 12-23개월 아 동의 단어목록을 연구한 Pae (1993)에 따르면, 이 시기에 아동이 발 화하는 것으로 보고된 최초의 동사는 '주다, 가다’이다. 또한 부모 가 보고한 18-36개월 아동의 단어목록을 바탕으로 초기 동사발달 을 연구한 Lee, Choi, Chang-Song과 Lee (2008)에서 18개월의 아 동이 발화한 초기 동사는 '가, 뽀뽀해, 안아, 앉아, 사랑해, 안 해, 자, 일어나, 꺼, 나가, 먹어, 박수 쳐, 신어’ 등이었다. 한편 12-23개월 아 동의 자발화에 등장하는 용언을 분석한 Lee와 $\operatorname{Im}(2003)$ 의 연구에 서는 18 개월에 등장하는 동사는 '주다, 하다, 되다'가 있었다. 동화 책에 등장하는 용언을 분석한 본 연구에서는 0-2세(0-23개월) 도서 에 등장하는 동사 중 '하다'의 사용빈도가 가장 높았고 그 뒤를 이 어 '놀다, 먹다, 오다, 켜다, 업다, 타다, 가다’가 모든 동사 사용빈도의 약 $60 \%$ 를 차지하는 고빈도 단어들이었다. 부모보고나 아동의 자 발화 분석에 기초한 선행연구들의 결과를 동화책 단어 분석에 기 초한 본 연구결과와 비교하여 그 결과를 해석하는 데는 주의를 기 해야 한다. 그러나 언어입력환경으로서 기능하는 동화책 단어와 실 제 아동이 발화하는 단어를 비교하여 아동이 동화책을 통하여 어 떤 언어자극을 받는지 살펴보는 것은 의미 있는 작업이라고 생각된 다. 선행연구들과 본 연구결과를 비교해 볼 때, 단어를 수집하는 연 구방법(부모보고, 자발화 분석, 동화책 단어분석)에 따라 만 2 세 이 전 아동의 초기 동사는 서로 다른 유형을 보이는 것으로 나타났다.

한편 본 연구에서 0-2세(만 0-23개월)에서 3-4세(만 24-47개월) 로의 전환기는 용언의 수와 비율이 증가하면서 문장구성 능력이 발달하며, 영어와는 달리 한국어에서는 동사가 급격히 증가하는 동사 폭발기가 있는 시기이다(Choi, 2000; Choi \& Gopnik, 1995;
Lee, Park, Park, \& Kim, 2003). 만 2-5세 아동의 자발화를 분석한 $\mathrm{Oh}$ 등(2014)의 연구에서, 이 시기에 해당하는 만 2 세와 3 세 사이에 동사 유형 수와 사용빈도가 유의미하게 증가하였다. 한편 이 시기 용언의 양과 사용빈도의 급격한 증가와 아동의 구문발달과 밀접한 관련이 있다고 보고되고 있다. 예를 들면, Lee 등(2003)은 22-41개 월 아동의 자발화샘플에서 용언의 유형수와 사용빈도는 평균낱말 길이, 평균형태소길이와 유의미한 높은 상관관계가 있다고 밝히고 있다. 동화책 단어를 분석한 본 연구에서도 이 시기에 연령이 증가 할수록 동사의 유형 수와 사용빈도가 증가하였다. 따라서 동화책 을 통하여 아동들은 이전보다 더 다양한 종류의 동사에 빈번하게 노출되면서 동사 양을 증폭시켜 동사폭발과 구문발달을 가속시킬 것이다.

\section{형용사}

형용사의 경우, 모든 연령 사이에서 유형 수가 유의미한 데 비해 사용빈도는 0-2세와 3-4세, 0-2세와 5-7세 사이에서만 유의미하였 다. 따라서 아동들은 연령이 증가하면서 동화책을 통해 더욱 다양 한 종류의 형용사를 접할 수 있고, 0-2세용 동화책에서보다는 3-4 세용 동화책에서 형용사에 더 빈번하게 노출되고, 5-7세용 동화책 에서는 사용빈도의 변화 없이 이전에 접한 형용사에 반복 노출된 다고볼수있다.

각 연령대별 사용빈도 누적이 $50 \%$ 를 차지하는 고빈도 형용사를 살펴보면, 0-2세용 도서에서는 '맛있다, 예쁘다, 싫다, 고맙다, 같다' 와 같이 아동의 구체적인 감정표현과 관련된 형용사가 주를 이루 고, 3-4세용 도서에서는 '있다, 그러하다, 없다, 좋다, 크다, 커다랗다, 이러하다'와같이 주로 대상의 상태를 표현하는 형용사가 나타나는 대신 구체적인 감정표현과 관련된 형용사는 감소하였다. 5-6세용 도서에서는 '있다, 없다, 좋다, 크다, 고맙다, 재미있다, 그러하다, 작 다'가 고빈도 형용사로 등장하는데 이들은 대상의 상태를 표현하 는 형용사뿐 아니라 구체적인 감정을 표현하는 형용사로 3-4세용 동화책에서 보다 더 자주 등장한다는 것을 알 수 있다. 따라서 나이 가 어린 아동을 위한 동화책일수록 구체적인 감정을 표현하는 형용 사가 주로 사용되고, 동화책을 보는 대상 연령이 높아질수록 다양 한 감정과상태를 표현하는 형용사가 함께 사용됨을 알수 있다.

한편, 2-5세 아동이 산출하는 형용사 전체에서 사용빈도 상위 30 위까지 분석한 Oh 등(2014)의 연구에서 2-5세 아동은 상위 6위 까지는 추상적인 형용사(예: ‘있-, 이렇-, 그렇- 등)를, 7-10위까지는 기본 상태표현 형용사(예: 싫-, 좋-, 아프- 등)를, 이후 30 위까지는 반 의어 쌍을 갖고 있는 형용사(예: 있다/없다, 덥다/춥다 등)를 사용하 는 특징을 보였다. 이에 비해 동화책에서는 사용빈도 상위 30 위까 
지 다양한 특성을 가진 형용사가 Oh 등(2014)의 연구에 나타난 순 위와상관없이 등장하고 있었다.

형용사 습득순서 중, 크기형용사는 개념적으로 단순하고, 지각 적으로 두드러지며, 사용빈도가 높기 때문에 다른 형용사에 비해 먼저 습득한다(Cho, 2000). Cho (2000)에 의하면, 2-6세 아동은 수 용어휘로서의 크기형용사 중 '크다'를 가장 먼저 습득한 후 '작다, 길다, 높다, 짧다, 넓다, 두껍다, 깊다, 굵다, 좁다, 얇다, 낮다, 얕다, 가 늘다' 순으로 습득하고, 표현어휘로서의 크기형용사 중 '크다, 작다, 높다, 두껍다, 짧다, 깊다, 넓다, 길다, 좁다 굵다, 얕다, 낮다, 가늘다' 순으로 습득한다. 본 연구에서 동화책에 등장한 형용사의 경우, 0-2세용 동화책에는 '크다, 높다, 작다, 조그맣다'가, 3-4세용 동화책 에는 '커다랗다, 깊다, 길다, 넓다, 짧다'가, 5-7세용 동화책에는 '낮 다, 굵다'가 처음 등장하는 크기형용사이다. 따라서 동화책 각 연령 대에 등장하는 크기형용사는 취학 전 아동의 자발화수용·표현 어 휘에 등장하는 크기형용사 습득순서와 비교적 잘 일치한다고 볼 수 있다.

\section{보조용언}

보조동사의 경우, 0-2세, 3-4세, 5-7세 사이의 유형 수와 사용빈 도가 모두 유의미하여 대상 연령이 높을수록 보조동사의 종류와 사용빈도가 증가함을 알 수 있다. 자발화를 분석한 Oh 등(2014)의 연구에서 '보-, 주-'가 전체보조동사 사용빈도의 $45 \%$ 를 차지하는 데 비해, 본 연구에서는 사용빈도 1 위와 2 위인 '주-, 보-'가 전체보조 동사 사용빈도의 $31.1 \%$ 를 차지하여 자발화보다 동화책에서 더 다 양한 보조동사를 사용하고 있음을 알 수 있다. 연령별 고빈도 보조 동사를 살펴보면, 0-2세용 동화책에서는 사용빈도 1위인 '주-'가 사 용누적비율이 $46.2 \%$ 를 차지한 데 비해, 3-4세용 동화책에서는 사 용빈도 1 위에서 4 위인 '지-, 보-, 있-, 주-'가 사용누적비율 $49.1 \%$ 를, 5-7세용 동화책에서는 사용빈도 1위에서 4위인 '주-, 있-, 않-, 하-'가 사용누적비율 $53.1 \%$ 를 차지하여 고빈도 보조동사의 종류와 누적 비율이 연령에 따라 변화함을 알 수 있다.

보조형용사의 경우, 0-2세와 3-4세 사이에서만 유형 수와 사용 빈도에서 유의미한 차이가 없었다. 즉 0-2세용 동화책에서는 '싶-' 이 유일하게 등장한 보조형용사였고, 3-4세용 동화책에서는 '싶-'이 외에 '었-, 않-, 프-'가 사용되어 동화책 대상 연령이 높아져도 적은 개수의 보조형용사를 반복하여 사용하고 있음을 알 수 있다.

\section{지정사}

긍정지정사 ‘이’는 연령이 증가할수록 사용빈도가 유의미하게 증 가하였고, 부정지정사 ‘아니’는 연령이 증가함에 따라 사용빈도가
증가하였으나 유의미한차이는 아니었다.

\section{동화책 용언어휘의 활용 및 제한점}

동화책 용언어휘는 다양한 상황과 맥락에서 일관적이고 반복적 으로 아동들에게 노출되는 언어입력자극으로서 아동의 용언습득 과 발달에 긍정적인 영향을 미친다고 볼 수 있다. 특히 동화책에 등 장하는 동사와 보조동사의 경우 연령이 증가할수록 다양한 종류 의 동사와 보조동사가 더 빈번하게 나타나기 때문에 용언의 습득 및 발달과 함께 구문발달에도 이바지 할 것이다. 따라서 중재 프로 그램 및 실험연구를 위한 목표단어를 선정할 때 용언목록을 활용 할 수 있겠다. 예를 들면, 용언사용능력에 제한을 보이는 정신지체 아동(Hwang \& Cho, 2008; Kim, 2004)을 대상으로 한 중재 프로그 램 및 실험연구에서 표준화된 어휘검사도구와 자발화를 기초로 만 들어진 표현어휘목록 이외에 수용어휘목록이 필요할 경우, 동화책 어휘를 기초로 만들어진 용언목록을 활용할 수 있을 것이다. 또한 동화책은 목표단어를 여러 가지 상황과 맥락에서 제공하는 장점이 있으므로 맥락에 따라 다양하게 사용되는 용언을 습득하는 데에 도 도움이 될 것이다.

본 논문은 문어자료 말뭉치 개발을 위해 수집된 데이터의 일부 를 분석한 말뭉치 어휘목록의 예비자료로서의 한계점을 지니고 있 다. 말뭉치로서의 역할을 하려면 텍스트의 분량, 집단을 대표하는 대표성, 자료의 균형성을 고려해야 한다(Choi \& Park, 2012). 텍스 트의 분량 면에서 말뭉치로서의 역할을 하기 위해서는 텍스트 분 량이 약 50,000어절이 필요(Choi \& Park, 2012)한 데 비해 본 연구 는 총 14,728 어절을 분석한 한계점이 있다. 또한 자료의 균형성 측 면에서, 분석대상이 된 동화책의 종류 중 창작동화가 39 권, 번역동 화가 38 권 분석에 포함된 데 비해 전래동화는 단 1 권만 포함되어 창 작동화와 번역동화에 포함된 단어들 중심으로 자료분석이 이루어 졌을 가능성이 높다. 그러나 전래동화의 경우 난이도에 문제가 있 다는 Lee와 Kim (2004)의 연구를 참고하여, 전래동화를 포함시킬 경우 자료의 균형성뿐 아니라 아동 연령에 따른 난이도도 고려할 필요가 있다. 또한 번역 동화책을 분석대상으로 할 때, 동화책의 내 용에 따라 발생할 수도 있는 문화적 차이가 어휘 빈도에 미치는 영 향을 고려하여야 하겠다.

\section{REFERENCES}

Akhtar, N., \& Tomasello, M. (2000). The social nature of words and word learning. In R. M. Golinkoff, et al. (Eds.), Becoming a word learner: a debate on lexical acquisition (pp. 115-135). Oxford: Oxford University Press. 
Cha, M. K., Kang, E. S., \& Jang, J. S. (2008). The development research on foundation of children library books. Seoul: The National Library for Children \& Young Adults.

Chang-Song, Y. K. (2004). Early lexical development of Korean infants: 8-17 months. Korean Journal Psychology: General, 23, 77-99.

Chang-Song, Y. K., Hong, S., \& Lee, K. (2007). The effect of amount and interactional styles maternal inputs on early vocabulary acquisition: a longitudinal multilevel modeling perspective. Proceedings of the Korean Psychological Association Annual Conference, 2007, 106-107.

Chang, K. H., Jeon, E. J., \& Kim, S. H. (2014). A study of the developmental tendency on the infant's acquisition of auxiliary verbs. Korean Language and Literature in International Context, 63, 283-314.

Cho, H. J. (2000). A study of language acquisition and developmental process of preschool children: centering on dimensional adjectives. Journal of Child Education, 9, 163-171.

Cho, Y. H., \& Lee, H. J. (2004). The role of comparison and lexical information in Korean child's acquisition of novel adjectives. Korean Journal of Developmental Psychology, 17, 197-212.

Choi, S. (2000). Caregiver input in English and Korean: use of nouns and verbs in book-reading and toy-play contexts. Journal of Child Language, 27, 69-96.

Choi, S. J., \& Park, B. (2012). Korean language informatics. In J. Y. Shin, et al. (Eds.), Introduction to Korean grammar. Seoul: Jisikkwakyoyang.

Choi, S., \& Gopnik, A. (1995). Early acquisition of verbs in Korean: a crosslinguistic study. Journal of Child Language, 22, 497-529.

Han, M. K., Seong, S. Y., \& Choi, S. J. (2015). Words in storybooks as children's language input environment: substantives. Communication Sciences \& Disorders, 20, 490-499.

Hart, B., \& Risley, T. R. (1995). Meaningful differences in the everyday experience of young American children. Baltimore, MD: Paul H. Brookes Publishing.

Huttenlocher, J., Haight, W., Bryk, A., Seltzer, M., \& Lyons, T. (1991). Early vocabulary growth: relation to language input and gender. Developmental Psychology, 27, 236-248.

Hwang, B. M., \& Cho, E. K. (2008). A study on use of verb and adjective of children with mild mental retardation. Journal of Speech-Language \& Hearing Disorders, 17, 55-64.

Kang, B. M., \& Kim, H. K. (2004). Frequency analysis of Korean morpheme and word usage. Seoul: Korea University, Research Institute of Korea Studies.
Kim, J. H., \& Lee, M. J. (2001). The influence of storybook reading and children's gender on decontextualized language ability. Korea Journal of Child Care and Education, 25, 1-19.

Kim, S. J. (2004). The development of the predicates between normal children and children with mental retardation. Journal of Special Education, 11, 255-269.

Kim, T. K. (2013). The research on the actual condition of little library books. Seoul: National Library of Korea, Research Institute of Library and Information.

Lee, H. J., \& Kim, J. P. (2004). An analysis of vocabulary in storybooks for preschool children. Korean Journal of Communication Disorders, 9, 57-77.

Lee, H. R. (2009). A longitudinal study of emergence of the first verb and maternal linguistic inputs. Journal of Speech-Language \& Hearing Disorders, 18, 1-15.

Lee, H. R., Choi, Y. L., Chang-Song, Y. K., \& Lee, S. B. (2008). The early verb acquisition in Korean children. Journal of Speech-Language \& Hearing Disorders, $17,65-77$.

Lee, H., Park, C. I., Park, E. S., \& Kim, H. (2003). A study on the relationship between the children's development of predicates and syntactic ability. Korean Journal of Communication Disorders, 8, 20-40.

Lee, I. S., Lee, S. O., \& Chai, W. (1997). The language of Korea. Seoul: Singumunwhasa.

Lee, P. Y., Lee, J. H., \& Jeon, E. J. (2004). Study on the parts of speech development in babyhood. Bilingual Research, 25, 285-308.

Lee, P., \& Im, Y. (2003). The developmental stages of children's sentence constructing ability: a case of Korean children under 24 months. Journal of Korean Language Education, 14, 257-293.

Lim, S. K., \& Kim, M. S. (2013). The relationship between parents' book reading behavior and home literacy enviroment and their effect on a toddler's vocabulary. Korean Journal of Child Studies, 34, 1-19.

Nam, K. S., \& Ko, Y. G. (1993). The standard Korean grammar. Seoul: Tap Publishing.

Oh, J. H., Cha, J. E., Yoon, M. S., Kim, J. M., \& Chang, M. S. (2014). Predicates in the vocabulary of typically developing preschoolers. Communication Sciences \& Disorders, 19, 274-284.

Pae, S. (1993). Early vocabulary in Korean: are nouns easier to learn than verbs? (Doctoral dissertation). University of Kansas, Lawrence, KS.

Shin, J. Y., Chung, M. S., Hwang, H. S., Do, W. Y., Kim, W. K., Han, J. H., ..., \& Lee, B. W. (2012). Introduction to Korean grammar. Seoul: Jisikkwakkyoyang. 
Sosa, A. V. (2016). Association of the type of toy used during play with the quantity and quality of parent-infant communication. JAMA Pediatrics, 170, 132-137.
Tomasello, M. (1992). First verbs: a case study of early grammatical development. New York, NY: Cambridge University Press. 
Appendix 1. 분석대상이 된 동화책 목록

\begin{tabular}{|c|c|c|c|}
\hline 번호 & 연령 & 제목 & 장르 \\
\hline 1 & 0-2세 & 아가야 사랑해 & 번역동화 \\
\hline 2 & 0-2세 & 병아리 & 번역동화 \\
\hline 3 & 0-2세 & 포근포근 낮잠을 자요-낮잠자기 & 번역동화 \\
\hline 4 & 0-2세 & 깜깜해 깜깜해 & 번역동화 \\
\hline 5 & 0-2세 & 나는 누구 아기일까요? & 번역동화 \\
\hline 6 & 0-2세 & 아가야, 너는 $\cdots \cdots$ & 번역동화 \\
\hline 7 & 0-2세 & 업어 줘 업어 줘 & 번역동화 \\
\hline 8 & 0-2세 & 나하고 놀자 & 번역동화 \\
\hline 9 & 0-2세 & 으앙으앙 & 창작동화 \\
\hline 10 & 0-2세 & 아기가 아장아장 & 창작동화 \\
\hline 11 & 0-2세 & 내가 엄마해야지 & 창작동화 \\
\hline 12 & 0-2세 & 딸랑딸랑 딸랑곰 & 창작동화 \\
\hline 13 & 0-2세 & 쿨쿨쿨 잠자요 & 창작동화 \\
\hline 14 & 0-2세 & 뒹굴뒹굴 짝짝 & 창작동화 \\
\hline 15 & 0-2세 & 응가, 뿌지직 뽕 & 창작동화 \\
\hline 16 & 0-2세 & 머리 어깨 무릎 발 & 창작동화 \\
\hline 17 & 0-2세 & 나도 나도 & 창작동화 \\
\hline 18 & 0-2세 & 콩콩, 콩주세요 & 창작동화 \\
\hline 19 & 0-2세 & 냠냠냠 쪽쪽쪽 & 창작동화 \\
\hline 20 & 0-2세 & 엄마랑 뽀뽀 & 창작동화 \\
\hline 21 & 0-2세 & 잘잘잘 & 창작동화 \\
\hline 22 & 0-2세 & 코코코 해 보아요 & 창작동화 \\
\hline 23 & 0-2세 & 나비잠 & 창작동화 \\
\hline 24 & 0-2세 & 타세요 타세요 & 창작동화 \\
\hline 25 & 0-2세 & 딸기 하나 둘 셋 & 창작동화 \\
\hline 26 & 0-2세 & 누구야 & 창작동화 \\
\hline 27 & 3-4세 & 내 친구 보푸리 & 번역동화 \\
\hline 28 & 3-4세 & 앗, 그림책이 살아 있어! & 번역동화 \\
\hline 29 & 3-4세 & 난 참이 참 좋아 & 번역동화 \\
\hline 30 & 3-4세 & 수박씨를 삼켰어! & 번역동화 \\
\hline 31 & 3-4세 & 늑대가 나는 날 & 번역동화 \\
\hline 32 & 3-4세 & 바다이야기 & 번역동화 \\
\hline 33 & 3-4세 & 세상의 많고 많은 초록들 & 번역동화 \\
\hline 34 & 3-4세 & 민들레는 민들레 & 번역동화 \\
\hline 35 & 3-4세 & 비가 톡톡톡 & 번역동화 \\
\hline 36 & 3-4세 & 엄마, 거꾸로 매달리면 잠이 올까요 & 번역동화 \\
\hline 37 & 3-4세 & 아기똥꼬 & 번역동화 \\
\hline 38 & 3-4세 & 아빠도 우리도 & 번역동화 \\
\hline 39 & 3-4세 & 생각연필 & 번역동화 \\
\hline 40 & 3-4세 & 너랑 안 놀아 & 번역동화 \\
\hline
\end{tabular}

\begin{tabular}{|c|c|c|c|}
\hline 번호 & 연령 & 제목 & 장르 \\
\hline 41 & 3-4세 & 우리 엄마 어디 있어요 & 번역동화 \\
\hline 42 & 3-4세 & 크르르르륵 잠자리 대소동 & 번역동화 \\
\hline 43 & 3-4세 & 내 이름은 제동크 & 창작동화 \\
\hline 44 & 3-4세 & 여름 숲 모뽀리 소리 & 창작동화 \\
\hline 45 & 3-4세 & 내가 먼저 인사해요 & 창작동화 \\
\hline 46 & 3-4세 & 난난난 & 창작동화 \\
\hline 47 & 3-4세 & 도서관 가는 날 & 창작동화 \\
\hline 48 & 3-4세 & 봄 숲 봄바람 소리 & 창작동화 \\
\hline 49 & 3-4세 & 즐거워서 깔깔깔 & 창작동화 \\
\hline 50 & 3-4세 & 누가 그랬어 & 창작동화 \\
\hline 51 & 3-4세 & 양말이 좋아 & 창작동화 \\
\hline 52 & 3-4세 & 괴물을 보았어 & 창작동화 \\
\hline 53 & 5-7세 & 특별한 책 & 번역동화 \\
\hline 54 & 5-7세 & 말말말 & 번역동화 \\
\hline 55 & 5-7세 & 눈사람 아저씨와 눈강아지 & 번역동화 \\
\hline 56 & 5-7세 & 난 귀염둥이가 아니야! & 번역동화 \\
\hline 57 & 5-7세 & 다른 쪽에서 & 번역동화 \\
\hline 58 & 5-7세 & 나는 잘하는 게 하나도 없어요 & 번역동화 \\
\hline 59 & 5-7세 & 자연은 우리 친구야! & 번역동화 \\
\hline 60 & 5-7세 & 큰집 작은집 & 번역동화 \\
\hline 61 & 5-7세 & 내 모자 어디 갔을까 & 번역동화 \\
\hline 62 & 5-7세 & $\begin{array}{l}\text { 팔랑팔랑 버들 잎 여행-나뭇잎이 알려주 } \\
\text { 는 자연의 순환 }\end{array}$ & 번역동화 \\
\hline 63 & 5-7세 & 우리 엄마야 & 번역동화 \\
\hline 64 & 5-7세 & 평화란 어떤 걸까 & 번역동화 \\
\hline 65 & 5-7세 & 내 이름을 불러주세요 & 번역동화 \\
\hline 66 & 5-7세 & 고맙습니다, 정말 고맙습니다 & 번역동화 \\
\hline 67 & 5-7세 & 도깨비 방망이 & 전래동화 \\
\hline 68 & 5-7세 & 한밤의 선물 & 창작동화 \\
\hline 69 & 5-7세 & 엄마는 회사에서 내 생각해? & 창작동화 \\
\hline 70 & 5-7세 & 특별한 친구들 & 창작동화 \\
\hline 71 & 5-7세 & 책 요정 초초 & 창작동화 \\
\hline 72 & 5-7세 & 숲까말은 기죽지 않는다 & 창작동화 \\
\hline 73 & 5-7세 & 귀신이 가득한 집 & 창작동화 \\
\hline 74 & 5-7세 & 강아지와 염소 새끼 & 창작동화 \\
\hline 75 & 5-7세 & 커다란 사과가 데굴데굴 & 창작동화 \\
\hline 76 & 5-7세 & 괴물이 나타났다! & 창작동화 \\
\hline 77 & 5-7세 & 꼴찌라도 괜찮아 & 창작동화 \\
\hline 78 & 5-7세 & 개구쟁이 아빠 & 창작동화 \\
\hline
\end{tabular}




\section{국문초록}

\section{아동의 어휘발달 촉진을 위한 언어입력환경으로서의 동화책 어휘 연구: 용언을 중심으로}

\section{한민경 · 성시연 · 최서진}

이화여자대학교 언어병리학

배경 및 목적: 본 연구에서는 동화책에 사용되는 어휘 중 용언의 유형과 사용빈도 등 그 형태적 특징을 알아보고 동화책에 등장하는 용언의 활용방안을 모색하고자 하였다. 방법: 0-2세, 3-4세, 5-7세용 동화책 각 연령대에서 선정한 26권씩 총 78권의 동화책에 등장하는 총 14,728 어절 중 동사, 형용사, 보조동사, 보조형용사, 긍정지정사, 부정지정사 등 용언에 해당되는 5,388 어절의 품사별 유형 수와 사용 빈도를 계산하고, 연령별 유형 수와 사용빈도의 차이를 살펴보았다. 결과: 동화책에 등장하는 용언은 동화책에서 사용되는 어휘 전체 유형 수의 $25.9 \%$, 어휘 전체 사용빈도의 $18.7 \%$ 를 차지하였고, 동화책 대상 연령이 높을수록 유형 수와 사용빈도가 증가하였다. 품사별 유형 수는 동사 $>$ 형용사 $>$ 보조동사 $>$ 보조형용사 $>$ 긍정지정사 $=$ 부정지정사의 순서로 많았고, 사용빈도는 동사 $>$ 형용사 $>$ 보조동사 > 긍정지정사>보조형용사>부정지정사의 순서로 높았다. 동화책 대상 연령이 높을수록 동사는 유형 수와 사용빈도가 유의미하게 증 가하였으나, 형용사는 유형 수와 사용빈도가 모두 유의미하게 감소하였고, 보조용언은 유형 수는 유의미하게 감소하나 사용빈도는 유 의미하게 증가하였다. 논의 및 결론: 동화책에서 사용되는 용언 품사 중 동사와 보조동사의 경우 동화책 대상 연령이 높아질수록 다양 한 종류가 빈번하게 사용되는 것으로 나타나 동화책은 아동의 구문발달에 긍정적인 영향을 미치는 언어입력환경을 제공하는 것으로 보인다.

핵심어: 용언, 동화책, 형태소분석, 유형 수, 사용빈도

본 연구는 정부(교육부)의 재원으로 BK21 플러스 사업의 지원을 받아수행된 연구임.

\section{참고문헌}

강범모, 김흥규(2004). 한국어 형태소 및 어휘 사용 빈도의 분석. 서울: 고려대학교 민족문화연구원.

김수진(2004). 정신지체아동과 일반아동의 용언 발달: 단어구조에 따른 비교. 특수교육연구, 11, 255-269.

김정화, 이문정(2001). 유아의 성별과 동화책을 즐겨읽는 정도가 유아의 탈상황적 언어능력에 미치는 영향. 한국영유아보육학, 25, 1-19.

김태경(2013). 작은 도서관 장서구성실태 현황 조사: 도서관연구소 2013년도 하반기 자체연구. 서울: 국립중앙도서관 도서관연구소.

남기심, 고영근(1993). 표준국어문법론. 서울: 탑출판사.

신지영, 정명숙, 황화상, 도원영, 김원경, 한정한, 김의수, 변정민, 유혜원, 최경봉, 이동혁, 김혜영, 차준경, 차재은, 김서형, 김지혜, 최석재, 박병선, 이봉

원(2012). 십게 읽는 한국어학의 이해. 서울: 지식과 교양.

오재혁, 차재은, 윤미선, 김정미, 장문수(2014). 2-5세 일반 아동의 어휘 발달: 용언. 언어청각장애연구, 19, 274-284.

이익섭, 이상억, 채완(1997). 한국의 언어. 서울: 신구문화사.

이필영, 이준희, 전은진(2004). 유아의 품사 범주 발달에 관한 연구. 이중언어학, 25, 285-308.

이필영, 임유종(2003). 한국 아동의 문장 구성 능력 발달 단계:24개월 이전의 한국 영·유아를 대상으로. 한국어 교육, 14, 257-293.

이현정, 박창일, 박은숙, 김향희(2003). 아동의 구문발달에 따른 용언의 발달. 언어청각장애연구, 8, 20-40.

이현진, 김주필(2004). 유아용 동화책의 어휘 분석 연구. 언어청각장애연구, 9, 57-77.

이희란(2009). 초기 동사 발달과 언어적 입력의 영향-종결어미의 소통기능을 중심으로. 언어치료연구, 18, 1-15.

이희란, 최유리, 장유경, 이승복(2008). 부모보고를 통해 종단 관찰한 한국 아동의 초기 동사발달. 언어치료연구, 17, 65-77.

임수경, 김명순(2013). 만 2 세 영아-어머니, 영아-아버지의 그림책 읽기행동 및 가정문해환경과 영아의 어휘력 간의 관계. 아동학회지, 34, 1-19.

장경희, 전은진, 김수현(2014). 유아의 보조 용언 습득 경향에 관현 연구. 국제어문, 63, 283-314. 
장유경(2004). 한국 영아의 초기 어휘발달: 8개월-17개월. 한국심리학회지: 일반, 23, 77-99.

장유경, 홍세희, 이근영(2007). 어휘습득에서 어머니의 언어적 입력과 상호작용 유형의 영향 한국심리학회 학술대회자료집, 2007, 106-107. 조윤희, 이현진(2004). 한국 아동의 형용사습득에서 비교와 어휘적 정보의 역할. 한국심리학회지: 발달, 17, 197-212.

조행자(2000). 아동의 언어 습득과 그 발달과정에 관한 연구. 유아교육, 9, 163-171.

차미경, 강은슬, 장지숙(2008). 어린이도서관 기초 장서 개발 연구. 서울: 국립어린이청소년도서관.

최석재, 박병선(2012). 국어 정보학. 신지영 외(편). 십게 읽는 한국어학의 이해. 서울: 지식과 교양.

한민경, 성시연, 최서진(2015). 동화책 어휘를 통해 살펴 본 아동의 언어입력환경: 체언을 중심으로. 언어청각장애연구, 20, 490-499.

황보명, 조은경(2008). 경도 정신지체 아동의 용언 사용능력에 관한 연구. 언어치료연구, 17, 55-64. 